\title{
Genetic Variability for Grain Iron, Zinc and Yield Contributing Traits in Pearl Millet [Pennisetum glaucum (L.) R. Br.]
}

\author{
Shankar Lal Yadav ${ }^{1}$, Vikas Khandelwal ${ }^{2 *}$, B. S. Rajpurohit ${ }^{1}$, \\ C. Tara Satyavathi ${ }^{2}$ and Manisha Kumari ${ }^{1}$
}

${ }^{1}$ Department of Genetics \& Plant Breeding, College of Agriculture, Agriculture University, Jodhpur-342 304, Rajasthan, India

${ }^{2}$ ICAR-AICRP on Pearl Millet, PC Unit, ARS, AU, Mandor, Jodhpur-342 304,

Rajasthan, India

*Corresponding author

\section{A B S T R A C T}

Keywords

Pearl Millet,

Genetic variability;

Heritability;

Genetic advance,

Iron, Zinc, Yield

Article Info

Accepted:

15 September 2020

Available Online:

10 October 2020
Genetic variability of grain iron, zinc, yield and its contributing traits in pearl millet were studied in 30 genotypes (R-line). An experiment was carried out during Kharif-2018 at the Research Farm of ICAR-AICRP on Pearl Millet, Project Coordinating Unit, Mandor, Jodhpur. Analysis of variance showed high significant variance among the genotypes for all the characters, under study, indicated availability of wide spectrum of variability among the genotypes. Highest magnitudes of PCV and GCV were observed for zinc content whereas, the lowest for days to maturity. High estimate of heritability along with high genetic advance as percentage of mean were observed for days to $50 \%$ flowering, plant height, number of productive tiller per plant, panicle length, panicle diameter, stover yield per plant, grain yield per plant, 1000 grain weight, harvest index, iron content and zinc content suggested additive gene action for expression of these characters. Hence, these characters may be proved as effective criteria for selection to improve seed yield in pearl millet whereas high heritability values with moderate genetic advance as percentage of mean were observed for days to maturity and protein content.

\section{Introduction}

Pearl millet (Pennisetum glaucum (L.) R. Br.) is commonly known as Bajra, Cat-tail or Bulrush millet in different parts of the world. It belongs to family Poaceae (Gramineae). Pearl millet is a diploid species having chromosomes number $2 n=14$. It is a highly cross-pollinated crop due to protogynous nature.
Pearl millet is an outstanding crop and is endowed with enormous variability for agronomically important traits in populations adapted to diverse agro-ecological conditions. Pearl millet is an important cereal crop in an arid and semi-arid region of the world. It is predominantly grown as a staple food grain and source of feed and fodder. It is believed to have originated in Africa (Vavilov, 1950), from where it's spread to India and other 
countries. Indian subcontinent is the largest producer of Pearl millet.

The grain contains 8.5 to 15 percent protein, 5.03 to 6.0 percent fat, 5 to 70 percent carbohydrates, Fe content ranging from 18 to $135 \mathrm{ppm}$ and $\mathrm{Zn}$ content 22 to $92 \mathrm{ppm}$ (Rai et $a l ., 2012)$. Micronutrients, including iron and zinc, are essential elements for a balanced human nutrition, required in small amounts. These two minerals are essential for human well-being and an adequate iron and zinc supply helps prevent, respectively, iron deficiency anemia and strengthen the immune system, which are two frequent problems in developing countries (Blair et al., 2009).

In 2017-18, pearl millet was cultivated in country on about 7.5 million hectares with a production of $9.07 \mathrm{MT}$ and an average productivity of $1305 \mathrm{~kg} / \mathrm{ha}$ (Anonymous, 2017-18). Rajasthan, Gujarat, Uttar Pradesh and Haryana are the major pearl millet growing states in India. In the state of Rajasthan, the area under this crop is 42.36 lakh ha, which is $56.48 \%$ of the national acreage. The total production of pearl millet in the state is 48.40 lakh tonnes, which is $53.36 \%$ of the national production with an average productivity of $1143 \mathrm{~kg} / \mathrm{ha}$ (Anonymous 2017-18).

Genetic variability defined as the formation of individuals differing in genotype, or the presence of genotypically different individuals, in contrast to environmentally induced differences which, as a rule, cause only temporary, nonheritable changes of the phenotype. The possibility of achieving improvement in any crop plants depends on the magnitude of genetic variability. Heritability specifies the proportion of the genotypic variance to the total phenotypic variance. It is a good index for the transmission of characters from parents to the offspring's (Falconer, 1960).
Genetic advance is the difference between the mean genotypic value of selected lines and mean genotypic value of parental population (original population before selection). The study of genetic advance is equally important as it measures the genetic gain based on the selection in a particular character. High genetic advancement coupled with high heritability estimates offers the most suitable condition for selection (Johnson et al., 1955). Therefore, for any crop improvement programme through selection, the study of genetic variability and heritability together with genetic advance will be more useful.

\section{Materials and Methods}

The investigation was conducted during the principal cropping season; kharif-2018, at Research farm of ICAR-AICRP on Pearl Millet, Project Coordinating Unit, Mandor, Jodhpur. The material comprised of 30 genotypes (R-line) of pearl millet which were sown in a Randomized Block Design (RBD) with three replications. Each genotype was sown in $4 \mathrm{~m}$ length of two rows with spacing of $60 \mathrm{~cm}$ between rows and $15 \mathrm{~cm}$ between plants. The recommended agronomic practices were followed to raise a good crop. The observations were based on the five randomly selected plants from each genotype and replication for different agromorphological traits i.e. plant height $(\mathrm{cm})$, number of productive tillers per plant, panicle length $(\mathrm{cm})$, panicle diameter $(\mathrm{cm})$, stover yield per plant $(\mathrm{g})$, grain yield per plant $(\mathrm{g})$, 1000 -grain weight (g) and harvest index $(\%)$. The observation for days to $50 \%$ flowering and days to maturity was recorded on the plot basis. Iron and Zinc estimation was done by using Atomic Absorption Spectrophotometer by following the method proposed by Jackson (1973). While, the nitrogen content of pearl millet genotypes was determined by the Kjeldhal method using a KEL PLUS distillation unit (Pelican Equipment, Chennai, 
India). The crude protein content of the sample was calculated as 6.25 times its nitrogen content and expressed as percentage. The data was subjected to analysis of variance (Panse and Sukhatme, 1985), coefficients of variation (Burton, 1652 and Johnson et al., 1955), heritability in broad sense and genetic (Johnson et al., 1955) as per the standard statistical methods. Statistical analysis was performed using WindoStatversion 9.1 software.

\section{Results and Discussion}

In the present study, the analysis of variation showed highly significant differences among the genotypes for all the 13 characters indicating the existence of considerable genetic variation in the 30 genotypes of pearl millet. The analysis of variance (Table 1) showed highly significant differences among the genotypes for all the thirteen traits viz., days to $50 \%$ flowering, days to maturity, plant height $(\mathrm{cm})$, number of productive tillers per plant, panicle length $(\mathrm{cm})$, panicle diameter (cm), stover yield per plant (g), grain yield per plant $(\mathrm{g})$, 1000-grain weight $(\mathrm{g})$, harvest index $(\%)$, protein content $(\%)$, iron content (ppm) and zinc content (ppm) indicating the presence of considerable genetic variability among the experimental material. Present results showed similar trend with earlier reported by Sumathi et al., (2010), Amiribezadi et al., (2012), Mukesh et al., (2013), Subi and Idris (2013), Vinodhana et al., (2013), Bika and Shekhawat (2015), Sumathi et al., (2016), Bhasker et al., (2017), Nehra et al., (2017), Kausik et al., (2018) and Sharma et al., (2018).

High magnitudes of PCV and GCV were observed (Table 2) for the traits viz., zinc content recorded PCV (42.63\%) and GCV (42.01\%) followed by number of productive tiller per plant $(38.31 \%, 35.33 \%)$, grain yield per plant $(36.30 \%, 32.51 \%)$, stover yield per plant $(35.80 \%, 31.76 \%)$, iron content $(33.65 \%, 33.31 \%), \quad 1000$ grain weight $(27.85 \%, 26.99 \%)$, panicle length $(24.66 \%$, $24.22 \%)$, panicle diameter $(24.41 \%, 23.14 \%)$ and harvest index $(24.10 \%, 21.51 \%)$. These results indicated greater scope for selection of these characters for further improvement programme because of substantial variability present in genotypes (R-lines) for these traits. This finding is substantiated by similar results reported by Sumathi et al., (2010) reported high GCV and PCV for the trait panicle length, panicle diameter, plant height, grain yield per plant and number productive tiller per plant, Vinodhana et al., (2013) reported high GCV and PCV for grain yield per plant, panicle length, 1000 grain weight and number of productive tiller per plant. Nehra et al., (2017) reported high GCV, PCV for panicle diameter, number of productive tiller per plant and 1000 grain weight. Talawar et al., (2017) reported the high values of GCV, PCV for number of productive tiller per plant, panicle length and grain yield per plant.

Moderate GCV and PCV reported for plant height $(17.64 \%, 16.78 \%)$ and days to $50 \%$ flowering $(13.45 \%, 13.02 \%)$, this result indicates that there was the little role of an environmental component in the observed variation. Similar results found by Bika and Shekhawat (2015) reported moderate GCV, PCV for trait days to $50 \%$ flowering, plant height. Talwar et al., (2017) also reported moderate GCV, PCV for plant height and days to $50 \%$ flowering.

Low GCV and PCV were reported for protein content $(9.80 \%, 8.08 \%)$ and days to maturity $(6.61 \%, 6.48 \%)$. That indicated the selection of these characters might not be effective. Similar works were reported by Choudhary et al., (2012) report low GCV, PCV for protein content. Bhasker et al., (2017) reported low GCV and PCV for days to maturity. 
Table.1 Analysis of variance (ANOVA) for grain iron, zinc, yield and its contributing traits

\begin{tabular}{|c|c|c|c|c|c|c|c|c|c|c|c|c|c|c|}
\hline \multirow[t]{2}{*}{ Source } & \multirow[t]{2}{*}{ DF } & \multicolumn{13}{|c|}{ Mean sum of squares } \\
\hline & & $\begin{array}{c}\text { Days to } \\
50 \% \\
\text { flowering }\end{array}$ & $\begin{array}{l}\text { Days to } \\
\text { maturity }\end{array}$ & $\begin{array}{c}\text { Plant } \\
\text { height } \\
\text { (cm) }\end{array}$ & $\begin{array}{c}\text { Number } \\
\text { of } \\
\text { productive } \\
\text { tillers per } \\
\text { plant }\end{array}$ & $\begin{array}{c}\text { Panicle } \\
\text { length } \\
(\mathrm{cm})\end{array}$ & $\begin{array}{l}\text { Panicle } \\
\text { diameter } \\
(\mathrm{cm})\end{array}$ & $\begin{array}{c}\text { Stover } \\
\text { yield per } \\
\text { plant (g) }\end{array}$ & $\begin{array}{l}\text { Grain } \\
\text { yield per } \\
\text { plant (g) }\end{array}$ & $\begin{array}{c}1000 \\
\text { grain } \\
\text { weight } \\
\text { (g) }\end{array}$ & $\begin{array}{c}\text { Harvest } \\
\text { index } \\
(\%)\end{array}$ & $\begin{array}{c}\text { Protein } \\
\text { content } \\
(\%)\end{array}$ & $\begin{array}{c}\text { Iron } \\
\text { content } \\
(\mathbf{p p m})\end{array}$ & $\begin{array}{l}\text { Zinc } \\
\text { content } \\
(\text { ppm) }\end{array}$ \\
\hline Replication & 2 & 6.34 & 1.20 & 58.03 & 0.27 & 1.61 & 0.05 & 314.07 & 54.53 & 0.50 & 0.27 & 1.24 & 16.63 & 22.01 \\
\hline Genotype & 29 & $130.65 * *$ & $89.6 * *$ & $1507.92 * *$ & $2.83 * *$ & $66.3 * *$ & $0.75 * *$ & $1622.42 * *$ & $251.91 * *$ & $12.44 * *$ & $119.17 * *$ & $3.01 * *$ & $863.32 * *$ & $795.87 * *$ \\
\hline Error & 58 & 2.83 & 1.19 & 50.90 & 0.16 & 0.80 & 0.03 & 134.21 & 19.166 & 0.26 & 9.35 & 0.41 & 5.80 & 7.91 \\
\hline
\end{tabular}

Table.2 Mean, Range, Genotypic and Phenotypic coefficient of variation, Heritability (broad sense) and Genetic advance as \% of mean for grain iron, zinc, yield and its contributing traits

\begin{tabular}{|c|c|c|c|c|c|c|c|}
\hline \multirow[t]{2}{*}{ Character } & \multirow[t]{2}{*}{ Mean } & \multicolumn{2}{|c|}{ Range } & \multicolumn{2}{|c|}{ Coefficient of variation } & \multirow{2}{*}{$\begin{array}{c}\text { Heritability (\%) } \\
\text { (broad sense) }\end{array}$} & \multirow{2}{*}{$\begin{array}{l}\text { Genetic advance } \\
\text { as \% mean at } 5 \%\end{array}$} \\
\hline & & Min & Max & Genotypic & Phenotypic & & \\
\hline Days to $50 \%$ flowering & 50 & 34 & 66 & 13.02 & 13.45 & 93.78 & 25.98 \\
\hline Days to maturity & 84 & 77 & 101 & 6.48 & 6.61 & 96.12 & 13.09 \\
\hline Plant height $(\mathrm{cm})$ & 131.3 & 92.9 & 188.4 & 16.78 & 17.64 & 90.51 & 32.89 \\
\hline $\begin{array}{l}\text { Number of productive tillers per } \\
\text { plant }\end{array}$ & 2.7 & 1.0 & 4.3 & 35.33 & 38.31 & 85.05 & 67.12 \\
\hline Panicle length (cm) & 19.3 & 12.1 & 31.5 & 24.22 & 24.66 & 96.46 & 49.01 \\
\hline Panicle diameter $(\mathrm{cm})$ & 2.1 & 1.5 & 3.2 & 23.14 & 24.41 & 89.94 & 45.22 \\
\hline Stover yield per plant (g) & 70.1 & 30.2 & 133.5 & 31.76 & 35.80 & 78.71 & 58.04 \\
\hline Grain yield per plant (g) & 27.1 & 9.0 & 47.5 & 32.51 & 36.30 & 80.19 & 59.97 \\
\hline 1000 grain weight $(\mathrm{g})$ & 7.5 & 4.2 & 14.9 & 26.99 & 27.85 & 93.95 & 53.89 \\
\hline Harvest index (\%) & 28.1 & 12.3 & 40.5 & 21.51 & 24.10 & 79.66 & 39.55 \\
\hline Protein content $(\%)$ & 11.5 & 9.3 & 13.8 & 8.08 & 9.80 & 67.92 & 13.71 \\
\hline Iron content (ppm) & 50.6 & 29.7 & 106.1 & 33.31 & 33.65 & 98.01 & 67.94 \\
\hline Zinc content (ppm) & 38.6 & 19.2 & 96.7 & 42.01 & 42.63 & 97.08 & 85.26 \\
\hline
\end{tabular}


In the present study, high heritability coupled with high genetic advance as per cent of mean were observed for days to $50 \%$ flowering, plant height, number of productive tiller per plant, panicle length, panicle diameter, stover yield per plant, grain yield per plant, 1000 grain weight, harvest index, iron content and zinc content indicating lesser influence of environment in expression of these characters and may be governed by additive gene action, hence effective for simple selection. Similar results were in accordance with Vinodhana et al., (2013), Bika and Shekhawat et al., (2015), Nehra et al., (2017).

High heritability with moderate genetic advance as percent of mean was recorded for the characters viz, days to maturity and protein content. This indicates the presence of additive and dominance gene action and hence selection would be ineffective for these traits. These findings were reported by Choudhary et al., (2012).

\section{References}

Amiribehzadi, A., Satyavathi, C.T., Singh, S.P., Bharadwaj, C. and Singh, M.P. 2012. Estimation of heterosis in diverse cytoplasmic malesterile sources of pearl millet [Pennisetum glaucum (L.) R. Br.]. Annual Agricultural Research New Series, 33(4): 220-227.

Anonymous, 2017-18. Directorate of Economics and Statistics (DES), Ministry of Agriculture and Farmers Welfare (MoA\&FW), India.

Bhasker, K., Shashibhushan, D., Krishna, K.M. and Bhave, M.H.V. 2017. Genetic variability, heritability and genetic advance of grain yield in pearl millet [Pennisetum glaucum (L.) R. Br.]. International Journal of Pure \& Applied Bioscience,5(4): 1228-1231.

Bika, N.K. and Shekhawat, S.S. 2015. Genetic variability study in pearlmillet
[Pennisetum glaucum (L.) R. Br.] for green fodder yield andrelated traits. Electronic Journal of Plant Breeding, 6(2): 600-602.

Blair MW, Austudillo C, Grusak MA, Graham R and Beebe SE (2009). Inheritance of seed iron concentrations incommon bean (Phaseolus vulgaris L.). Molecular Breeding 23: 197-207.

Burton, G.W., Wallance, A.T. and Rachie, K.O. 1962. Chemical composition and nutritive value of [Pennisetum $\operatorname{glaucum}(\mathrm{L}$.$) R. Br.] of grain. Crop$ science 12: 187-189.

Choudhary, R., Jat, B.L., Anwala, R., Dhikwal, S.R. and Sharma, K.C. 2012.Studies on estimates of genetic variability and character association of yield components and protein content in pearl millet. Forage Research, 38(2): 80-85.

Falconer, D.S. 1981. Introduction to quantitative Genetics. Oliver Boyd, London, 340.

Jackson, M.L. 1973. Soil and Plant analysis. Prentice Hall of India Private Ltd, New Delhi.

Johnson, H.W., Robinson, H.F. and Comstock, R.E. 1955. Estimation of genetic and environmental variability in soybean. Agronomy Journal, 47: 314318.

Kaushik, J., Vart, D., Kumar, M., Kumar, A. and Kumar, R. 2018. Phenotypic diversity in pearl millet [Pennisetum glaucum (L.) R. Br.] germplasm lines. International Journal of Chemical Studies, 6(5): 1169-1173

Lush, J.L. 1949. Heritability of quantitative character in farm animals. Proceeding of American Society of Animal Production, 33: 293-301.

Mukesh S., S., Satyavathi, C.T., Singh, M.P., Bharadwaj, S., Singh, S.P.and Barthakur, S. 2013. Genetic variability and association studies in pearlmillet 
for grain yield and high temperature stress tolerance. Indian Journal of Dryland Agricultural Research and Devlopment, 28(2): 71-76.

Nehra, M., Kumar, M., Kaushik, J., Vart, D., Sharma, R.K., and Punia, M.S. 2017. Genetic divergence, character association and path coefficient analysis for yield attributing traits in pearl millet [Pennisetum glaucum (L.) R. Br] inbreds. Chemical Science Review and Letters, 6(21): 538-543.

Panse, V.G. and Sukhatme, P.V. 1978. Statistical Methods for Agriculture Workers. I.C.A.R., New Delhi. $3^{\text {rd }}$ Revised Edition.

Rai, K.N., Govindaraj, M., and Rao, A.S. 2012. Genetic enhancement ofgrain iron and zinc content in pearl millet. Quality assurance and safety of crops and foods, 4(3): 119-125.

Sharma, B., Chugh, L.K., Sheoran, R.K., Singh, V.K. and Sood M. 2018. Study on genetic variability, heritability and correlation in pearl millets germplasm. Journal of Pharmacognosy and Phytochemistry, 7(6): 1983-1987.
Subi,M.I.M. and Idris, A.E. 2013. Genetic variability, heritability and genetic advance in pearl millet [Pennisetum glaucum (L.) R.Br.] genotypes. British Biotechnology Journal, 3(1): 54-65.

Sumathi, P., Lalithkannan, R. and Revathi, S. 2016. Genetic analysis anddiversity studies in pearl millet [Pennisetum glaucum (L.) R. Br.].Electronic Journal of Plant Breeding, 7(4): 1014-1019.

Sumathi, P., Sumanthi, M., Vinodhana, N.K. and Sathyam 2010. Geneticvariability for different biometrical traits in pearl millet genotypes [Pennisetum glaucum (L.) R. Br.]. Electronic Journal of Plant Breeding, 1(4): 437-440.

Talawar, A.M., Girish, G., Channabasavanna, A.S. and Kitturmath., M.S. 2007. Studies on genetic variability, correlation and path analysis in pearl millet [Pennisetum glaucum (L.) R. Br.] germplasm lines. Agricultural Science Digest, 37(1): 75-77.

Vavilov, N.I. 1950. The origin Variation immunity and breeding of cultivated plants. Chronica Botanica, 13 (1): 366.

\section{How to cite this article:}

Shankar LalYadav, Vikas Khandelwal, B. S. Rajpurohit, C. Tara Satyavathi and Manisha Kumari. 2020. Genetic Variability for Grain Iron, Zinc and Yield Contributing Traits in Pearl Millet [Pennisetum glaucum (L.) R. Br.]. Int.J.Curr.Microbiol.App.Sci. 9(10): 1927-1932. doi: https://doi.org/10.20546/ijcmas.2020.910.235 